\title{
The Development of Audio-Visual Learning Media in Islamic Cultural History Subject for Eight Grade Students of MT's Al-Amanah, Jeneponto
}

\author{
Ihdiana $^{1^{*}}$, Ismail Tolla ${ }^{2}$, Jumadi $^{3}$ \\ ${ }^{123}$ Department of Educational Science, Universitas Negeri Makassar \\ Makassar, Indonesia \\ ${ }^{*}$ Corresponding author's email: ishakihdiana [AT] gmail.com
}

\begin{abstract}
The problem in this research were: what is the level of learning implementation and learning achievement of History and Culture of the VIII grade students of MTs Al-Amanah in Jeneponto Regency? The purpose of this study is to describe: An overview of the implementation of learning and learning achievement levels History of Islamic culture in class VIII students of MTs Al-Amanah in Jeneponto Regency. This research was development research $(R \& D)$. Development research was research which was oriented towards the development or refinement of a science in overcame a problem directly through an action and self-reflection based on the results of the research, which aimed to improve or enhance educational services that must be carried out in the context of classroom learning. Based on the research results that have been described in the previous chapter, the research results were formulated as follows: Achievement of learning Islamic History and Culture using audio-visual media Students of class VIII MTs Al-Amanah in Jeneponto Regency has a significant increase. Of the 38 students at Madrasa Tsanawiyah Al-Amanah Jeneponto Regency, 20 people got the high category and 13 people got the high enough category after taking action using audiovisual media. Different things before being given the action of using audio-visual media in Islamization learning material activities in South Sulawesi.
\end{abstract}

Keywords--- Learning, Media, Audio Visual

\section{INTRODUCTION}

\subsection{Background of The Problem}

The development of audio-visual based learning media for students at VIII grade Madrasah Tsanawiyah MTs AlAmanah Jeneponto Regency is expected to be able to overcome the gap between expectations and reality. The intended hope is that the teacher is able to carry out the learning process of the history of Islamic Culture by using audio-visual media and utilizing relevant learning materials based on the learning needs of Islamic Cultural History at VIII grade Madrasah Tsanawiyah. The next hope is that students can learn to the maximum and improve learning achievement and the ability to understand aspects related to the field of the history of Islamic Cultural.

The reason for the importance of this development is relevant to the learning media development model developed by [1] that the development of interactive multimedia-based media is sought to be as operational as possible as a reference in developing interactive multimedia-based learning media products. The interactive multimedia-based learning media development model consists of three stages, that is the define stage, the design stage, and the development stage [1].

Based on this fact, teachers experience obstacles in teaching students the History of Islamic Culture. In addition, the selection of research locations in Jeneponto Regency is based on the efforts of the Ministry of Religion in an effort to maximize teachers to be able to transform Islamic-based subjects in the Madrasah education environment. The program certainly creates a dilemma for teachers, on the one hand, having the integrity to carry out these demands well, on the other hand, teachers face students who need more innovation by teachers to achieve these targets. Therefore, this development research is a step to support the Ministry of Religious Affairs program of the Republic of Indonesia.

Based on the assumptions on the above background, the researcher viewed it as important to solve learning problems with limited media in learning the history of Islamic Culture at Madrasa Tsanawiyah Al-Amanah in Jeneponto Regency. Thus the researcher intended to conduct a research entitled "Development of Audio-visual Based Learning Media in Learning the History of Islamic Culture for Class VIII Students at Madrasah Tsanawiyah Al-Amanah, Jeneponto Regency". 


\subsection{Formulation of The Problem}

The problems that will be examined in this research are as follows: What are the level of learning implementation and learning achievement of History and Culture of the VIII grade students of MTs Al-Amanah in Jeneponto Regency?

\subsection{The Objective of The Study}

The purpose of this study is to describe: An overview of the implementation of learning and learning achievement levels History of Islamic culture in class VIII students of MTs Al-Amanah in Jeneponto Regency.

\subsection{The Significance of The Study}

The results of this study are expected to provide the significances both theoretically and practically. Theoretical Significance is contributing thoughts in the form of innovation in learning the history of Islamic Culture at Madrasah Tsanawiyah. As input for teachers to add insight and knowledge about learning the history of Islamic Culture at Madrasah Tsanawiyah. Provide input for further researchers, especially about learning the history of Islamic Culture at Madrasah Tsanawiyah using audio-visual learning media.

Practical Significance is The information obtained in the study is expected to be used as a basis for teachers of the history of Islamic Culture subjects at schools that are research locations in taking steps to improve and improve the quality of the history of Islamic Culture learning by using audio-visual learning media, Provide input on the teaching of the history of Islamic Culture, especially the implementation of teaching the history of Islamic Culture using audio-visual learning media, Teachers are expected to increase knowledge about the history of Islamic Culture learning techniques using audiovisual learning media, Students with research results are expected to increase their learning achievement in terms of learning the history of Islamic Culture by using audio-visual learning media.

\section{THEORETICAL REVIEW}

\subsection{The Definition of Learning Media}

Media in learning activities is often categorized by various education experts as a tool that has a function in supporting learning activities. Media comes from the word "medius" which means middle, intermediary, or introduction, [2]. Furthermore, [3] provided a limitation that learning media is a tool that has a function as a tool that can be used in conveying messages to students. In line with the views of [2] and [3], [4] argued that media is often used interchangeably with the term media as a tool or as a communication medium. For [4] communication will run smoothly when supported by tools that can simplify or streamline the communication process. [4] view provides reinforcement that the media is a practical tool in facilitating communication.

Learning activities, media have a very important role in supporting the implementation of learning well and making it easier to achieve learning goals. In this concept, media is something that is very much needed in supporting the achievement of learning targets that are planned as part of the planned process results. With this assumption, the learning media has very supportive benefits for the implementation of the teaching and learning process. The use of instructional media is also a creative and systematic effort to create experiences that can help students' learning process. This is because the media acts as a learning stimulant and can foster learning motivation so that students do not get bored easily in the teaching and learning process.

Based on the aforementioned assumptions, the media has the aim of forming students more interested in learning activities provided by the teacher. The arrangement of learning events is carried out carefully with the intention of making learning occur and making it effective. Therefore, learning needs to be designed, what media can be used, its objectives are determined before it is implemented, and its implementation is controlled [5]. Media becomes a formula in providing a supportive atmosphere for students, making it easier for teachers in the process of transforming knowledge to students.

\subsection{The Definition of The History of Islamic Culture}

Etymologically, the word history can be expressed in Arabic, namely the date, sirah or science of date, which means the provisions of the period or time, while the science of date means the science that contains or discusses the mention of events and the causes of these events [6]. The next definition Tarikh is defined as history, is a record relating to past events which are enshrined in written reports and a wide scope. Thus, Tarikh or History is a discussion of all human activities related to certain events in the past which are arranged systematically and chronologically, [7].

The History of Islamic Culture is mostly about the political history of Muslims, especially in the Middle East. The history of Islamic Culture is the history of the rise and fall of Muslim dynasties. More narrowly, the history of Islamic Culture is the history of the elite or it can be said that the history of Muslim rulers. On the other hand, culture is more likely to be understood as art. So the discussion about Islamic culture revolves around aspects of Islamic art, poetry, painting, calligraphy, and the like. Thus, the cultural history of Islam which is very politically oriented is the emergence of images that are not always accurate about Islam and Muslims, that they are more involved in the endless power struggle. Whereas 
Islamic history is not merely a political history, political history is only a small part of Islamic history as a whole which includes social, cultural, economic, and educational life.

The development process of Islam in Indonesia was also influenced by the development of Sufism. According to [8] in Islamic history, Sufism refers to the behavior of the Prophet Muhammad SAW and his companions. In addition, learning Islamic History and Culture cannot be separated from the process of spreading and developing Islam in Arabia and Indonesia. For example, the entry of Islam in the Kingdom of Luwu, the Kingdom of Gowa and Tallo, and the Kingdom of Bone to small kingdoms in South Sulawesi [9].

\subsection{Audio-visual Learning Media}

Audio-visual media cannot be separated from the use of computer-based information technology in learning activities. According to [2] audio-visual media is a media that is a combination of audio and visual or can be called a listening perspective media [2]. In general, audio-visual media is an intermediary medium or the use of the material and its absorption through sight and hearing so as to establish conditions that enable students to acquire knowledge, skills, or attitudes. Not only the application of media, the collaborative learning model according to [10] needs technology support. For [10], the collaborative learning model has five phases to promote interaction and mutual responsibility among learners to support the achievement of individual and team goals. Five general phases of collaborative learning consist of identifying learning tasks, team building and planning, individual learning, team learning, and sharing and evaluating learning outcomes [10]. These five can be transformed through the use of computer-based information technology in classroom learning activities.

Audio-visual media are used by using computer technology in learning activities. Computer technology is an invention that allows presenting any or all forms of stimulus so that learning will be more optimal [2]. Today, teaching can be said to be effective when a teacher uses a tool in the learning process in the form of computer technology. Effective learning can be said to be learning that optimally utilizes information and communication technology in the learning process as a tool. One of the uses of information and communication technology in learning is by using e-learning, [11]. In audio-visual media, the things that are important to pay attention to our reality, moving images or not, recorded writing and sound. These five aspects are important to get a stimulus because it will have an impact on students' interest in using audio-visual media. The teacher must have the ability to realize the five stimuli via network or computer use. These five things do not make it possible for every teacher to master them well because of the limitations of computer operation.

\subsection{Selection Criteria for Audio-visual Learning Media}

Determining the media to be used in a learning activity needs to be supported by careful consideration for each teacher so that the use of media is appropriate. [12] argued that learning conditions at Madrasahs still need extra attention to help students develop their potential. [13] stated that teachers are instructional designers who are involved in planning, developing, implementing, and teaching research. Development and application are part of the implementation of learning. Furthermore, the implementation of the learning process is part of class management (managerial function). [14] stated that the teacher's function in the classroom, are (1) teaching (instructional function), (2) educating (educational function), and managing the class (managerial function) in a professional manner. [15] stated that teaching is guiding students to experience the learning process. Effective teaching is teaching that can lead students to learn effectively.

Methods such as examples, analogies, models, interactive simulations, practice, and feedback, when applied appropriately, as in the plan analysis, program, can significantly enhance learning [16].

Based on the citation from [16] opinion, that the use of media is similar to the application of learning methods that aim to improve the quality of learning. Clark provided a limitation that in an applied learning method that is used is oriented towards improving learning outcomes.

\subsection{Teacher in Learning Implementation}

[15] suggested that teaching is guiding students to experience the learning process. Effective teaching is teaching that can bring students to learn effectively. Learning is an activity to find and see the subject matter. Meanwhile, according to [17], teaching is the creation of an environmental system that allows the learning process to occur. Teachers as learning managers who are ready to guide and assist students in their journey towards maturity in a complete and comprehensive manner.

[13] stated that teachers are instructional designers who are involved in planning, developing, implementing, and teaching research. Development and application are part of the implementation of learning. Therefore, learning design is the same as learning management function.

Based on the opinions of education experts above, it can be concluded that the teacher's duties in implementing learning in the classroom include: planning the learning, implementing the learning, and conducting assessments. 


\section{METHOD}

This research was a research and development (R\&D). The choice of this type of research was based on Whitehead's opinion in [18] which stated that there is a commitment to quality improvement, there is a clear intention to intervene in, increase one's understanding and practice, and to accept one's own responsibility.

This research was conducted at MTs in Jeneponto Regency in the odd semester of the 2019 school year for 12 weeks. As the research subject was one class in MTs Al Amanah students in Jeneponto Regency, that was class VIII.

The development of audio-visual media refers to the 4-D model of [19] with several modifications consisting of four stages, namely define, design, develop, disseminate.

The subjects in this study were students of MTs class VIII in Jeneponto Regency. The number of population research subjects was 38 students. The selection of research subjects was considered representative for the study to be held.

\section{RESULT AND DISCUSSION}

The preliminary analysis aims to define the main problems faced by grade VIII students of MTs Al-Amanah, Jeneponto Regency as objects or targets for developing audio-visual media. After the problem is identified, the next step is to formulate a solution to the problem or solution to the problem found. Recent analysis activities are carried out in two ways, namely by directly observing the learning activities of students and conducting interviews with each class teacher who is the object of the research. The research location specified was MTs. Al-Amanah class VIII, Jeneponto Regency. The preliminary data for analysis are as follows.

\subsection{Students Ability}

Based on the results of the researcher's observations at each research location, the researcher found that there were various abilities of students who did not know the history of Islamization in South Sulawesi, there were those who knew but were not in-depth, and some were able to tell and narrate the process of Islamization in South Sulawesi. The students who were identified as not mastering the Islamization process in South Sulawesi were evenly distributed in the research locations at MTs Al-Amanah which were 38 people. The whole students were then used as subjects who were given treatment, namely learning the Islamization process in South Sulawesi using the developed audio-visual media.

\subsection{Learning Process}

The teacher learning process still uses classical teaching patterns, that is using makeshift media and tends to use bag book-based media. When checking students at MTs Al-Amanah, Jeneponto Regency by asking students to tell pieces of the history of Islamization in South Sulawesi, the students were unable to tell pieces of the history of Islamization in South Sulawesi.

\subsection{Use of Media}

Teachers in the teaching and learning process use fewer media that attract students' attention and tend not to vary. Islamization teaching in South Sulawesi is not accompanied by a stimulus in the form of media that makes it easier for students to understand and master the history of Islamization in South Sulawesi.

\subsection{Teaching Material}

The teaching material in the 2013 curriculum does not consider the initial conditions of students who come from remote areas of Jeneponto Regency who tend to use relatively limited media because they only use makeshift media such as textbooks etc. Students tend to be slow in mastering the history of Islamization in South Sulawesi. Students in studying the history of Islamization in South Sulawesi are still varied, some have not mastered it and some have never read literature. Although the ability of students has not yet finished studying Islamization in South Sulawesi, the teacher still has to continue the material because the orientation is only to convey the material as a whole and tends to ignore students' understanding of the Islamization process in South Sulawesi.

\subsection{Students Condition}

The condition of students at MTs Al-Amanah, Jeneponto Regency who was the subject of the study had a public elementary school background, and only $14 \%$ had a Madrasah Ibtidaiyah elementary school background. Based on these conditions, the relative burden of teachers in teaching is rather heavy.

\subsection{Learning Pattern}

The learning pattern is still focused on the teacher (teacher-center) so that students act as active listeners. With a learning pattern like this, the cultivation of mastery of Islamization learning at MTs Al-Amanah is relatively less pro-students. 


\subsection{Teacher Educational Background}

There are still many teachers at MTs Al-Amanah who do not have a background in the discipline of Islamic Cultural History or general history, so that mastery of learning materials and methods for teaching at MTS is very limited.

The results of the initial identification above, describe the problems experienced by teachers and students in the learning process. Based on these problems, researchers developed audio-visual media which are expected to be a solution to these problems.

\subsection{Student Analysis}

The subjects in this media development research were students in class VIII MTs Al-Amanah in Jeneponto Regency. Student analysis is carried out by examining the characteristics of the subject as consideration for developing audio-visual media which includes; (a) the level of intellectual development and learning characteristics of students, (b) social conditions of the students. The results of the analysis of students were obtained based on information on the three research locations as follows:

The level of intellectual development and learning characteristics of students

In general, at the age of 12-13 years, the cognitive development of children is very dynamic to record everything they have learned. According to the theory of cognitive development by Dworetzky (1990), in [20] which [21] described as the preoperational period. At this age, it is very appropriate to impart knowledge to students because at that time children will find it easier to remember, imitate, and memorize what they have learned. Children at this age are also known as the beginner play and learning period. Children prefer and are attracted to something bright (full color), full of unique or interesting images. With these characteristics, students at the MTS studied were actually very enthusiastic about learning, let alone something new. This can be seen when researchers show reading books with lots of pictures, they are very interested in.

\section{Social Condition of The Students}

The background of students' mastery of Islamic history in their respective homes and in the social environment where students interact tends to have minimal information on Islamic history, especially information about the Islamic history of South Sulawesi carried over to the school environment.

This data is the basis for developing audio-visual learning media which is a combination of several methods so that it is possible to increase understanding of the history of Islamization in South Sulawesi.

This activity is carried out to formulate specific learning objectives, based on the analysis of concepts and assignments based on the basic competencies and indicators contained in the content standards and minimum completeness criteria that must be achieved by students in each basic competency.

The characteristics of students are one of the considerations that must be considered in preparing a learning aid. These characteristics concern the interests and talents of students, the tendency of learning styles, and the basic abilities of students. The characteristics of students are one of the variables of the teaching conditions. This variable is defined as the aspects or qualities of the individual learners. These aspects can be in the form of talents, interests, attitudes, the motivation of students, learning styles, thinking skills, and initial abilities (learning outcomes) that they already have. The characteristics of students will be very influential in the choice of management strategies, which are related to how to organize teaching, especially the components of teaching strategies, to suit the individual characteristics of students. Identification related to students, including age, gender, education level, socioeconomic level, background, learning styles, experiences, and attitudes.

The characteristics of students as above will be useful when we determine the goals that must be achieved, the selection and use of learning strategies that are considered suitable, and to determine relevant evaluation techniques [22]. According to [19], student analysis is a study of student characteristics in accordance with the design of learning device development. These characteristics include background academic abilities (knowledge), cognitive development, and individual or social skills related to the learning topic, media, format, and selected language. Student analysis is carried out to obtain a description of student characteristics, including (1) the level of ability or intellectual development, (2) individual or social skills they already have. [19] explained that the characteristics of students determine media decisions and formats such as language and presentation style. Information needed for students includes Subject competence, attitudes, language, and skills/abilities.

\subsection{Material Analysis}

Based on the results of observations in the three research schools, the material analysis conducted by researchers based on the content standards set by the government in the 2013 curriculum was deemed not in accordance with the development pattern of students' abilities. The availability of books and learning media for students is still limited. Although there are several books provided by the government, these books have not been able to teach the history of Islam in South Sulawesi 
to grade VIII students systematically or according to the students' abilities. The availability of books for class VIII students on the theme of Islamization in South Sulawesi is only at MTs Al-Amanah which is under the auspices of the Ministry of Religion which has not implemented the 2013 curriculum. The results of the material analysis are the basis for developing audio-visual media, because, with the results of the analysis of material needs, Islamization materials can be designed. in South Sulawesi for students according to their level or level of ability, so that quickly the history of Islamization in South Sulawesi.

\subsection{Task Analysis}

The purpose of task analysis in education is to prepare students so that in the future they become independent and productive humans. Education places more emphasis on individual growth and development as a person. The principles in these exercises can be used for practical educational purposes. In this task analysis theory, educators conduct a systematic task analysis of the tasks that students must do in training or educational situations. From this exercise, educators will know the extent to which students understand and understand the material that has been taught by the educator. Based on the objectives of the analysis on Islamization material in South Sulawesi with the following stages: (1) digging up information on the early entry of Islam in South Sulawesi, (2) then reading literature on the Islamization process (3) reading literature on the process of accepting Islam in South Sulawesi.

Based on the analysis of these tasks, what must be done so that these goals can be achieved include attention, motivation, and level of development. Learning will be effective if students show the stimulus well. Motivation is needed so that students are encouraged to respond to stimuli. Meanwhile, motivation itself is strongly influenced by the type and level of aspirations one has. In addition to attention and motivation, learning must also pay attention to the psychological properties and traits that determine the actions of students according to the stage of student development.

\section{CONCLUSION}

Based on the research results that have been described in the previous chapter, the research results were formulated as follows: Achievement of learning Islamic History and Culture using audio-visual media Students of class VIII MTs AlAmanah in Jeneponto Regency has a significant increase. Of the 38 students at Madrasa Tsanawiyah Al-Amanah Jeneponto Regency, 20 people got the high category and 13 people got the high enough category after taking action using audiovisual media. Different things before being given the action of using audio-visual media in Islamization learning material activities in South Sulawesi.

\section{REFERENCES}

[1] S. Yuliandari, "PENGEMBANGAN MEDIA PEMBELAJARAN BERBASIS MULTIMEDIA INTERAKTIF PADA MATA PELAJARAN EKONOMI MATERI JURNAL PENYESUAIAN PERUSAHAAN JASA,” Jurnal Pendidikan Akuntansi (JPAK), vol. 2, no. 2, Art. no. 2, Aug. 2014, Accessed: Feb. 15, 2021. [Online]. Available: https://jurnalmahasiswa.unesa.ac.id/index.php/jpak/article/view/9418.

[2] Rusman, D. Kurniawan, and C. Riyana, Pembelajaran berbasis teknologi informasi dan komunikasi : mengembangkan profesionalitas guru, 1st Ed. Jakarta: Rajawali Pers, 2012.

[3] C. L. Bovee, Business Communication Today. New York: Prentice Hall, 1997.

[4] O. Hamalik, Proses Belajar Mengajar. Jakarta: Bumi Aksara, 2004.

[5] Departemen Pendidikan Nasional, "DEPARTEMEN PENDIDIKAN NASIONAL PENGEMBANGAN SILABUS PDF Free Download," 2008. https://docplayer.info/52909482-Departemen-pendidikan-nasional-pengembangansilabus.html (accessed Feb. 15, 2021).

[6] J. Abdullah, "Pengertian Sejarah dan Pendidikan Islam - Kompasiana.com,” Kompasiana, Jun. $27,2015$.

[7] M. K. Supiana, Materi pendidikan agama Islam. Bandung: Remaja Rosdakarya, 2001.

[8] N. A. Ghaffar, "Tasawuf dan Penyebaran Islam di Indonesia," Rihlah: Jurnal Sejarah dan Kebudayaan, vol. 3, no. 01, Art. no. 01, Oct. 2015, doi: 10.24252/rihlah.v3i01.1374.

[9] R. Rahmawati, "Perspektif Baru dalam Proses Penyebaran Islam di Kerajaan Bone Sulawesi Selatan Indonesia pada Abad ke 17," Rihlah: Jurnal Sejarah dan Kebudayaan, vol. 3, no. 01, Art. no. 01, Oct. 2015, doi: 10.24252/rihlah.v3i01.1375.

[10] H. Suh, "International Journal for Educational Media and Technology," International Journal for Educational Media and Technology, vol. 5, no. 1, p. 12, 2011.

[11] N. S. Hanum, "Keefetifan e-learning sebagai media pembelajaran (studi evaluasi model pembelajaran e-learning SMK Telkom Sandhy Putra Purwokerto)," Jurnal Pendidikan Vokasi, vol. 3, no. 1, Art. no. 1, Feb. 2013, doi: 10.21831/jpv.v3i1.1584.

[12] N. Khodijah, "EVALUASI PROGRAM PENINGKATAN KULAIFIKASI GURU MADRASAH DI SUMATERA SELATAN," Jurnal Penelitian dan Evaluasi Pendidikan, vol. 16, no. 1, Art. no. 1, 2012, doi: 10.21831/pep.v16i1.1121. 
[13] Yamin, Strategi pembelajaran berbasis kompetensi. Jakarta: GP Press, 2007.

[14] T. Achmad, Strategi Belajar Mengajar Bahasa dan Sastra Indonesia. Makassar: Badan Penerbit UNM, 2005.

[15] Slameto, Belajar dan faktor-faktor yang mempengaruhinya. Jakarta: Rineka Cipta, 2003.

[16] R. E. Clark, "Dangers in the evaluation of instructional media," Academic Medicine, vol. 67, no. 12, pp. 819-20, Dec. 1992.

[17]P. Fathurrohman and S. Sutikno, Strategi Belajar Mengajar. Bandung: Refika Aditama, 2011.

[18] Kunandar, Langkah Mudah Penelitian Tindakan Kelas. Jakarta: Rajawali Pers, 2009.

[19] S. Thiagarajan, D. S. Semmel, and M. I. Semmel, Instructional Development for Training Teachers of Exceptional Children. University of Minnesota: Leadership training institute/special education, 1974.

[20] H. D. Brown, Principles of Language Learning and Teaching. USA: Longman, 2007.

[21] J. Piaget, Piaget's Theory, In P.H. Mussen (ed). Carmichael's Manual of Psychology. New York: Wiley, 1970.

[22] W. Sanjaya, Strategi Pembelajaran Berorientasi Standar Proses Pendidikan. Jakarta: Kencana, 2014.

[23] 